\title{
Late Quaternary environments and human occupation in the Murray River Valley of northwestern Victoria
}

\author{
A. L. Prendergast ${ }^{1}$ \\ J. M. Bowler ${ }^{2}$ \\ M. L. Cupper $^{2}$
}

\author{
${ }^{1}$ Geoscience Australia \\ Canberra 2601, Australia \\ ${ }^{2} S c h 000$ of Earth Sciences \\ University of Melbourne \\ Victoria 3010, Australia
}

\begin{abstract}
A multidisciplinary approach has been employed to study the environmental and cultural evolution of the Victorian Mallee. Regional geomorphic mapping of relict landforms and stratigraphic analyses reveal evidence of ongoing climatic oscillations in the central Murray Valley, where the Murray River system interacts with aeolian Mallee landscapes. Analysis of landforms using a land systems approach provides new insights into patterns of fluvial-aeolian interaction over the last glacial cycle. Five land systems are identified within the study area; three of these preserve evidence of palaeochannel activity markedly different from the present Murray River system. Fluvial morphology evolved over the late Quaternary from wide, laterally-migrating channels associated with source-bordering dunes to narrower, more sinuous regimes. An extensive archaeological record overprints the region, with radiocarbon and optically stimulated luminescence (OSL) dating revealing human presence in this landscape from at least $15,000 \mathrm{cal} \mathrm{BP.}$
\end{abstract}

Keywords: Australia; Mallee; Quaternary; environmental change; geomorphology; archaeology; oxygen isotopes; luminescence dating; radiocarbon dating; Alathyria jacksoni.

\section{Introduction}

The semi-arid central Murray Valley (Figure 1) preserves a wealth of evidence with which to reconstruct the environmental and cultural evolution in southeastern Australia. The lack of ice cover during glacial periods has ensured that a relatively complete record of climate change is preserved in sediments and landforms (Bowler and Magee 1978). In addition, the semi-arid fringes of southeastern Australia preserve 
one of the longest records of human occupation on the continent (Mulvaney and Kamminga 1999; O'Connell and Allen 2004).

This paper aims to investigate the impact of climate change over the last glacial cycle on the geological and archaeological records of the Mallee region. A detailed geomorphic and sedimentological study of fluvial, aeolian and lacustrine landforms provides the basis for interpreting climatic trends through the proxy of an evolving land system. In addition, archaeological survey and excavation reveals human interactions with this changing landscape. This evidence is integrated to construct a model of environmental evolution in the Mallee over the last glacial cycle.

\section{Materials and methods}

\section{Land systems mapping}

Land systems (Christian and Stewart 1952; Gerard 1981) and sediment mapping were carried out through satellite image (Landsat TM) and aerial photograph interpretation (River Murray Mapping Digital Colour Infrared Orthophotomap series, Murray-Darling Basin Commission 1996), supplemented with detailed field traverses. Stratigraphic logs were obtained by cleaning vertical sections along river banks and gullies, and by digging trenches. Soil development and sediment composition were assessed in the field and later confirmed through thin section analysis.

\section{Archaeological investigation and dating}

Archaeological survey was conducted in tandem with land systems mapping. North to south transects were surveyed at approximately one kilometre intervals from the base of the Woorinen Land System to the southern edge of the Murray River. The Woorinen Land System and the northern sideof the Murray River were not surveyed. Several previously unrecognised sites were identified (Figure 2, Table 3).

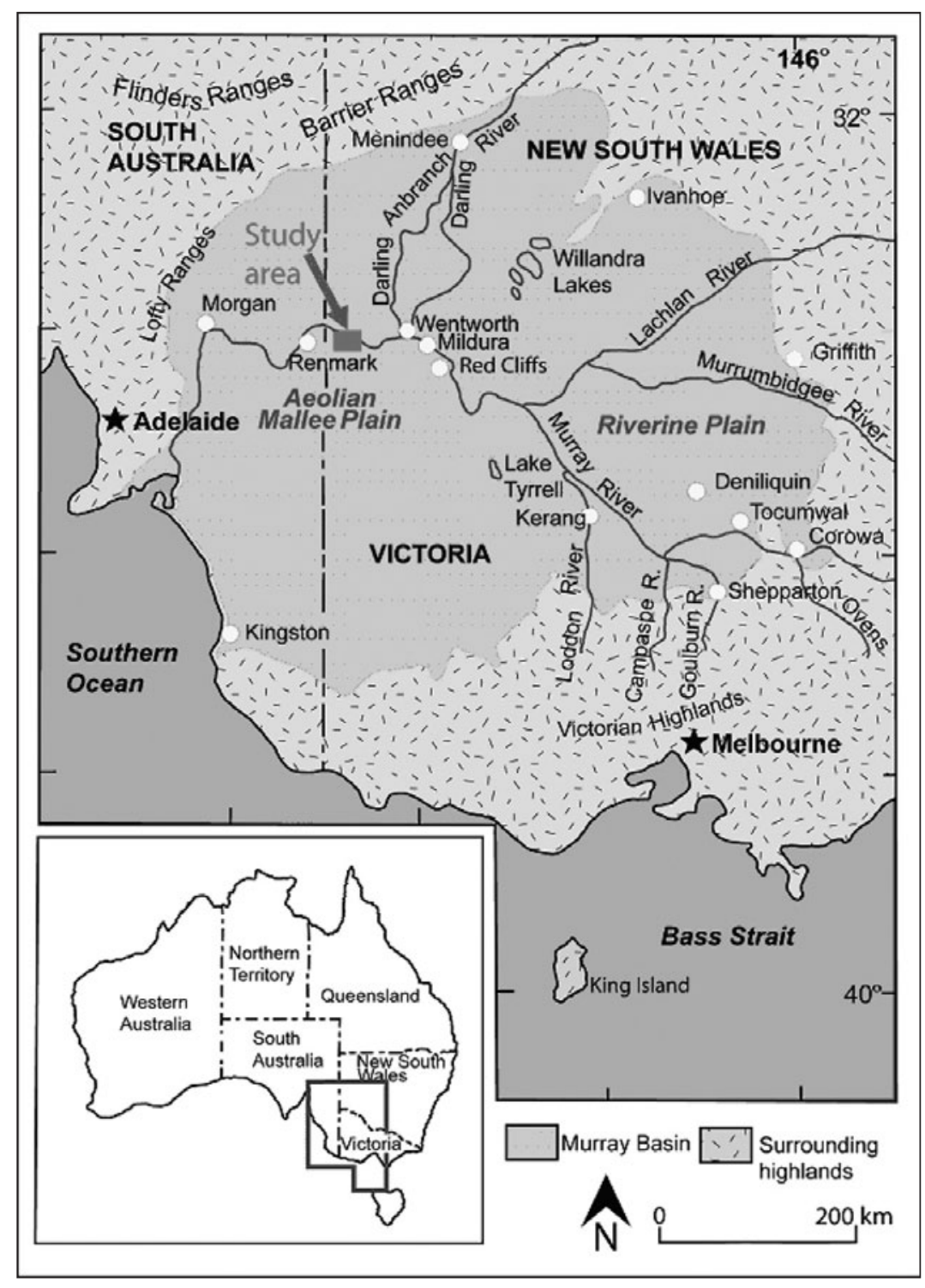

Figure 1. Map of the Murray Basin showing the location of the study area, the major drainage networks and the division between the Aeolian Mallee Plain and the Riverine Plain (adapted from Brown and Stevenson 1989). 

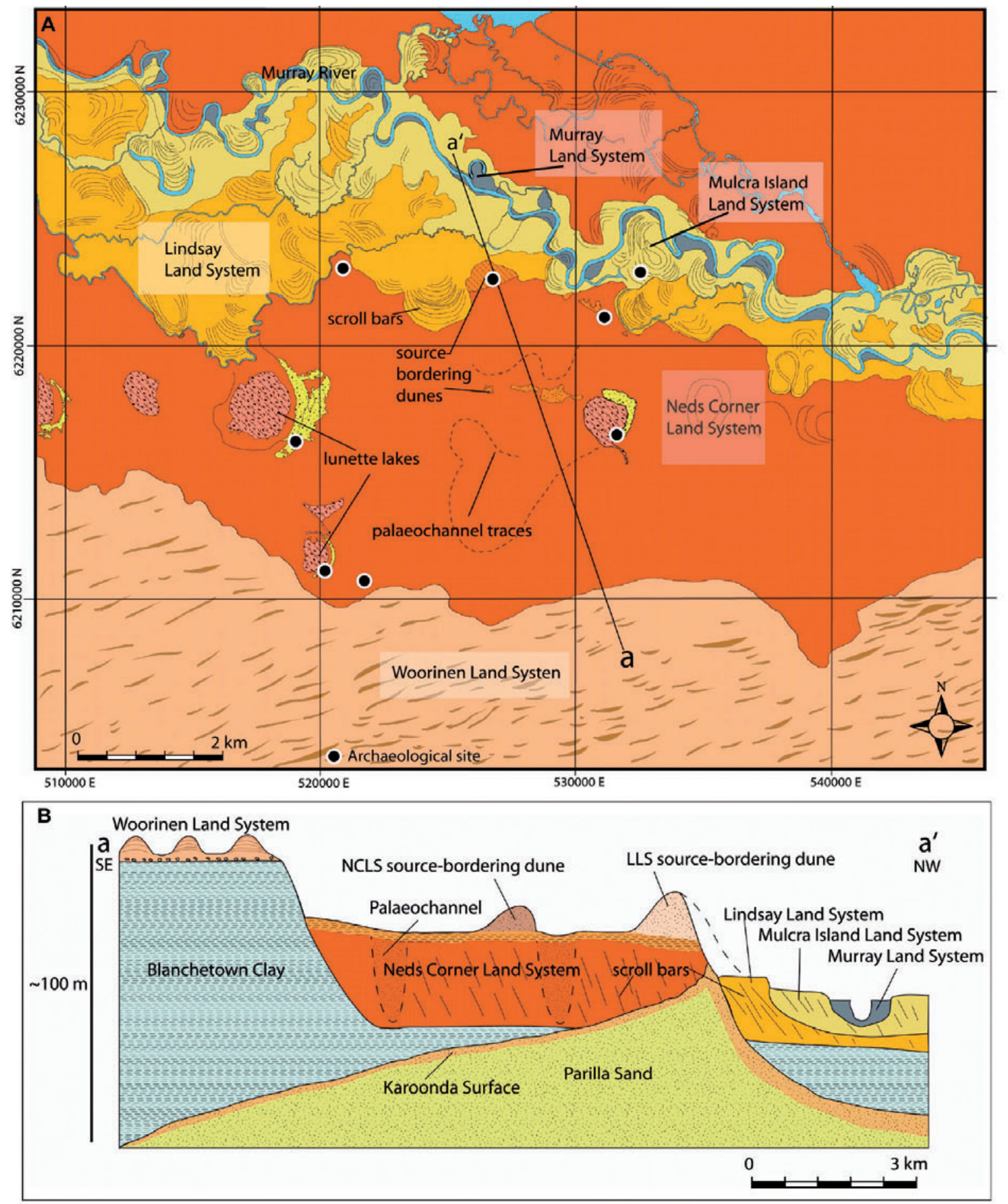

Figure 2.

A: Land systems map of the study area showing the locations of archaeological sites. From south to north the five land systems defined within the study area are: Woorinen Land System, Neds Corner Land System, Lindsay Land System, Mulcra Island Land System and Murray Land System. Within the land systems are land units of lunette lakes, palaeochannels and source bordering dunes. B: Schematic southeast to northwest cross section (a-a') of the study area. Vertical scale is exaggerated.

Two $1 \mathrm{~m} \times 1 \mathrm{~m}$ trenches were excavated in a previously unrecorded shell midden (the Homestead Midden: $\left.34^{\circ} 08^{\prime} 08.2^{\prime \prime} \mathrm{S}, 141^{\circ} 21^{\prime} 40.5^{\prime \prime} \mathrm{E}\right)$. All sediments were sieved and freshwater mussel shells (Alathyria jacksoni) were collected for radiocarbon dating at the Waikato Radiocarbon Dating Laboratory, New Zealand. 
Four OSL samples were obtained from above and below archaeological horizons by hammering $40 \mathrm{~mm}$ diameter stainless steel tubes into freshly cleaned vertical sediment faces. The 90-125 $\mu \mathrm{m}$ sediment fractions were retained for OSL dating at the University of Melbourne using standard pro cedures (Galbraith et al. 1999). Palaeodoses were calculated using a single aliquot regenerative dose (SAR) protocol using procedures described in Stone and Cupper (2003). Cosmic-ray dose rates were determined from established equations (Prescott and Hutton 1994).

\section{Land systems mapping}

Five land systems were defined via affinities in topography, pedology, sedimentology and vegetation. Each of these land systems was subdivided into land units, such as palaeochannels, lunettes or linear dunes. They are described sequentially from south to north in progression from highest to lowest elevation (Figure 2, Table 1). This broadly corresponds to a chronological description from the oldest to the youngest units.

\section{Woorinen Land System}

The Woorinen Land System comprises land units of east-west linear dunes and sand plains, which flank the southern margins of the study area. This system extends southwards to become part of the Central Mallee Land System described by Rowan and Downes (1963). The Woorinen Land System forms the uppermost topography of the study area, occurring around ten metres above the Neds Corner Land System (Figure 2, Table 1).

Several alternating phases of soil formation and aeolian activation have previously been identified within linear dune sequences throughout the Mallee (Churchward 1961; Bowler and Magee 1978). The last phase of dune activation occurred between $~ 25-15 \mathrm{ka}$, during and just after the last glacial maximum (Bowler and Magee 1978; Bowler 1980, 1986a; Wasson 1989; Readhead 1990). The chronology of linear dune palaeosol formation serves as a benchmark that is used in this study to correlate to the fluvio-aeolian-lacustrine units defined within the study area.

\section{Neds Corner Land System}

The Neds Corner Land System (Rowan and Downes 1963), situated around $10 \mathrm{~m}$ below the Woorinen Land System, extends throughout the study area as a large, flat terrace (Figure 2, Table 1). Although it is the dominant feature of the Murray Valley in this area, its soil-sedimentary components have not previously been analysed. The palaeochannel-floodplain and lunette-lake land units of the Neds Corner Land System preserve the best evidence of combined fluvial, aeolian and lacustrine interactions in the region.

Based on its relative position in the landscape, as well as its high pedogenic carbonate content (Figures 2, 3, Table 1), the Neds Corner Land System is interpreted to be the oldest of the four fluvial terraces identified in this study. Meander wavelengths and channel widths of the palaeochannels are substantially larger than in the presently active Murray Land System (Table 2). Two lunette lakes, Lake Wallawalla and Little Lake Wallawalla, occur as broad, low relief, oval depressions incised into the surface of the Neds Corner Land System (Figure 2). As the lakes overlie fluvial meander loops, their formation postdates the final phase of fluvial activity on the Neds Corner Land System. 


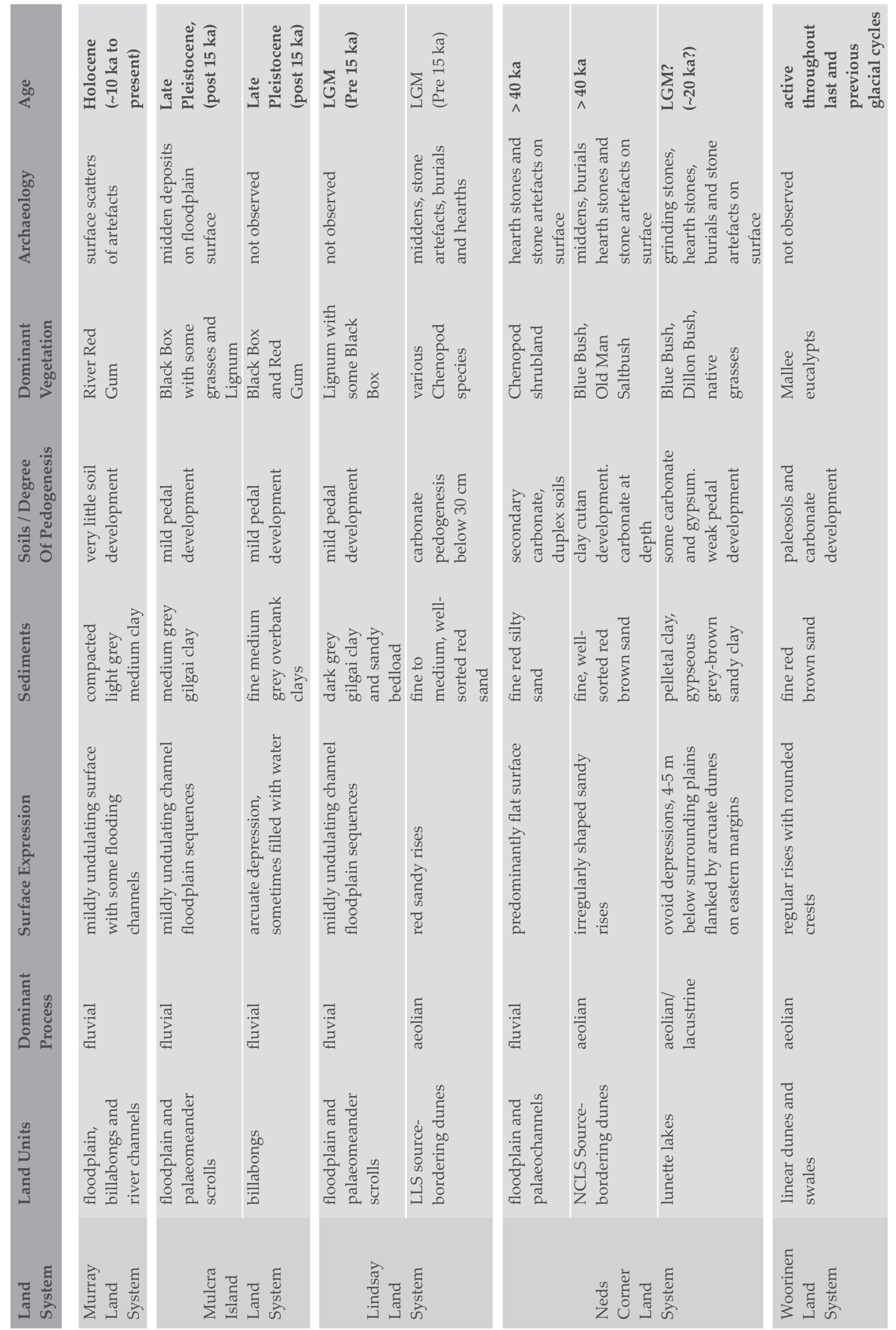

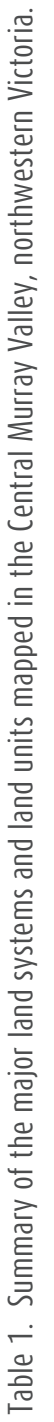




\begin{tabular}{|c|c|c|c|c|}
\hline & $\begin{array}{l}\text { Murray Land } \\
\text { System }\end{array}$ & $\begin{array}{l}\text { Mulcra Island } \\
\text { Land System }\end{array}$ & $\begin{array}{l}\text { Lindsay } \\
\text { Land System }\end{array}$ & $\begin{array}{l}\text { Neds Corner } \\
\text { Land System }\end{array}$ \\
\hline $\begin{array}{l}\text { Meander } \\
\text { geometry }\end{array}$ & highly sinuous & $\begin{array}{l}\text { moderately } \\
\text { sinuous }\end{array}$ & $\begin{array}{l}\text { laterally } \\
\text { migrating }\end{array}$ & $\begin{array}{l}\text { laterally } \\
\text { migrating }\end{array}$ \\
\hline $\begin{array}{l}\text { Meander } \\
\text { wavelength }\end{array}$ & $600 \mathrm{~m}$ & $800 \mathrm{~m}$ & $1000 \mathrm{~m}$ & $1200 \mathrm{~m}$ \\
\hline Channel width & $60 \mathrm{~m}$ & $75 \mathrm{~m}$ & $100 \mathrm{~m}$ & $150 \mathrm{~m}$ \\
\hline Fluvial load & suspended load & $\begin{array}{l}\text { mixed load to } \\
\text { suspended load }\end{array}$ & bedload & bedload \\
\hline Pedology & negligible & $\begin{array}{l}\text { soil forms in } \\
\text { peds }(1-5 \mathrm{~cm})\end{array}$ & $\begin{array}{l}\text { more pedal } \\
\text { development } \\
\text { than MILS, some } \\
\text { carbonate } \\
\text { accumulation } \\
\text { in source- } \\
\text { bordering dunes }\end{array}$ & $\begin{array}{l}\text { significant } \\
\text { dispersed and } \\
\text { blocky carbonate } \\
\text { accumulation }\end{array}$ \\
\hline Mineralogy & $\begin{array}{l}\text { quartz, clay, } \\
\text { feldspar, mica }\end{array}$ & $\begin{array}{l}\text { quartz, gilgai clay, } \\
\text { feldspar, mica }\end{array}$ & $\begin{array}{l}\text { quartz, gilgai clay } \\
\text { feldspar, mica } \\
\text { significant } \\
\text { carbonate }\end{array}$ & $\begin{array}{l}\text { quartz, clay, } \\
\text { feldspar, mica, } \\
\text { and carbonate } \\
\text { below } 30 \mathrm{~cm} / \\
\text { quartz with clay } \\
\text { cutans above } 30 \mathrm{~cm}\end{array}$ \\
\hline $\begin{array}{l}\text { Elevation } \\
\text { above present } \\
\text { Murray River } \\
\text { system }\end{array}$ & $\begin{array}{l}\text { present river } \\
\text { level }\end{array}$ & $1-2 \mathrm{~m}$ & $2-4 \mathrm{~m}$ & 6-8 m \\
\hline $\begin{array}{l}\text { Dominant } \\
\text { vegetation }\end{array}$ & River Red Gum & Black Box trees & Lignum & $\begin{array}{l}\text { Chenopod } \\
\text { shrubland }\end{array}$ \\
\hline
\end{tabular}

Table 2. Summary of the fluvial units observed in the Central Murray Valley, northwestern Victoria: MLS is the Murray Land System, MILS is the Mulcra Island Land System, LLS is the Lindsay Land System, NCLS is the Neds Corner Land System.

\section{Lindsay Land System}

The Lindsay Land System is a fluvio-aeolian system of floodplains, palaeochannels and source-bordering dunes. It sporadically outcrops between the Neds Corner Land System and the Mulcra Island Land System, with an average terrace width of $500 \mathrm{~m}$. Alternating vegetation bands of Black box trees and Lignum preserve evidence of large meander scrolls on Lindsay and Mulcra Islands (Figure 4a, 4d, Tables 1, 2).

\section{Mulcra Island Land System}

The Mulcra Island Land System typically sits 1-2 m above the Murray Land System, $1 \mathrm{~m}$ below the Lindsay Land System (where present) and 2-4 m below the Neds Corner Land System (Figure 2, Table 1). Its width ranges from 50 to $900 \mathrm{~m}$. The system is essentially composed of floodplain, palaeomeander scrolls and billabongs (Table 2).

\section{Murray Land System}

The Murray Land System includes the River Murray and its presently active floodplain. The terrace occupies the lowest point in the landscape, typically 1-2 m below the Mulcra Island Land System (Figure 2, Table 1). Floodplain width varies from 10 to $200 \mathrm{~m}$ (Table 2) and is vegetated with River Red Gum woodland. 


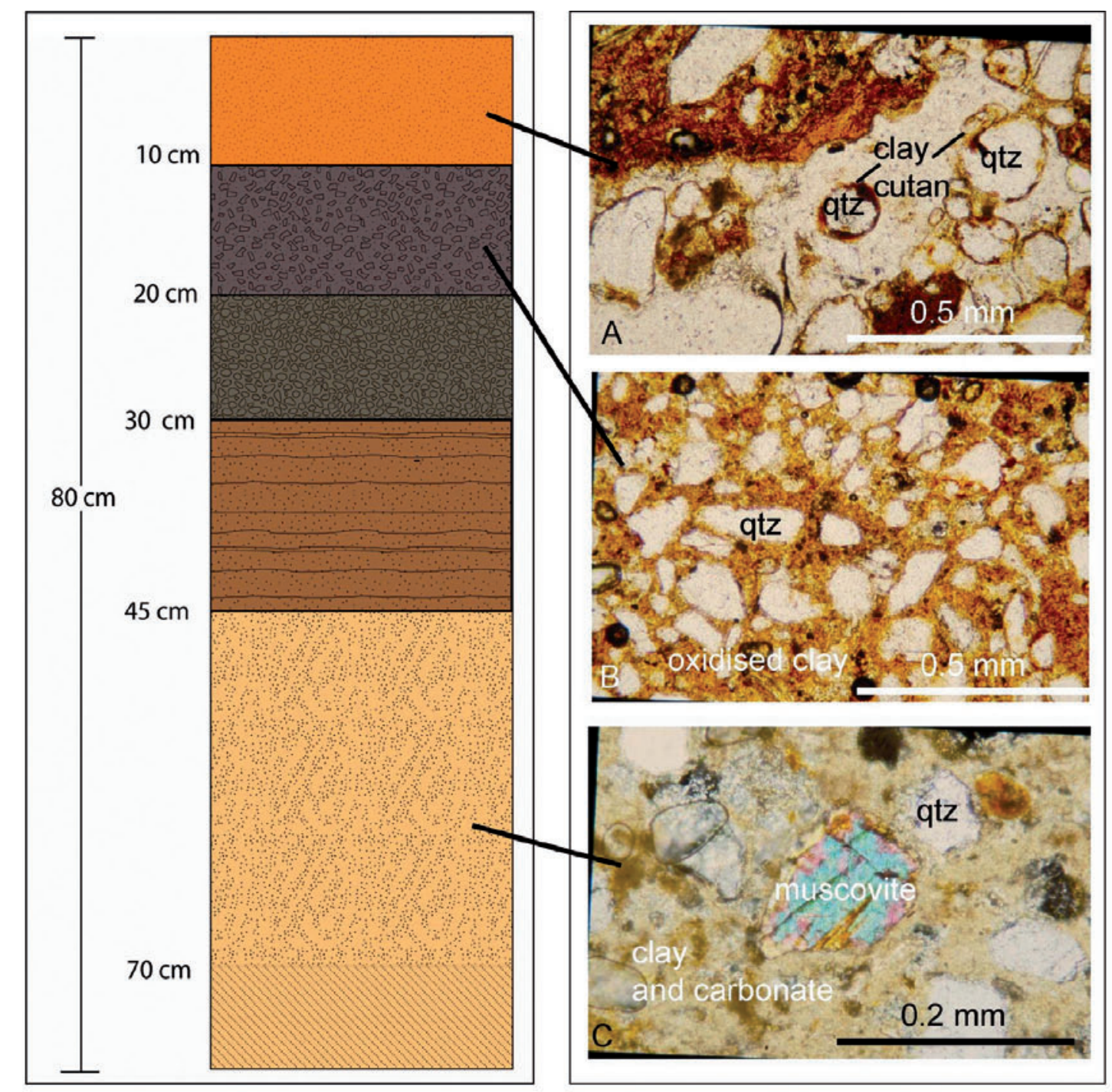

\begin{tabular}{|c|c|}
\hline $\begin{array}{l}\text { A-horizon: fine red-brown (5 YR 5/4) } \\
\text { silty sand. No pedal development }\end{array}$ & $\begin{array}{l}\text { Fine red-brown ( } 10 \mathrm{YR} 6 / 3 \text { ) silts and sands with } \\
\text { coarse blocky carbonate oriented in } \\
\text { plains } \sim 4 \mathrm{~cm} \text { thick }\end{array}$ \\
\hline $\begin{array}{l}\text { Greyish brown }(7.5 \text { YR } 6 / 2) \text { strongly } \\
\text { pedal (peds } \sim 1-2 \mathrm{~cm} \text { ) crumbly silty } \\
\text { clay }\end{array}$ & $\begin{array}{l}\text { Yellowish-brown (10 YR } 8 / 6) \text { calcareous silty clay } \\
\text { with abundant finely dispersed carbonate with red } \\
\text { silty sand infilling biotubules }\end{array}$ \\
\hline $\begin{array}{l}\text { Reworked greyish brown ( } 7.5 \text { YR } 6 / 2) \\
\text { crumbly silty clay and finely } \\
\text { dispersed carbonate }\end{array}$ & As above, overprinted with microcrystaline gypsum \\
\hline
\end{tabular}

Figure 3. Interpretative stratigraphic log from the Neds Corner Land System floodplain (34 $10^{\prime} 30^{\prime \prime}$ S, $\left.141^{\circ} 19^{\prime} 30.6^{\prime \prime} \mathrm{E}\right)$ with thin section photomicrgraphs.

A: Polycyclic clay cutans surrounding quartz grains in the upper $30 \mathrm{~cm}$ aeolian-dominated horizon;

B: Typical suspension-load quartz grains surrounded by clay cutans in the upper $30 \mathrm{~cm}$ aeolian-dominated horizon;

C: A muscovite flake amidst clay-rich pedogenic carbonate from the lower pedogenised fluvial horizon. For further thin section description and interpretations see Table 3. 

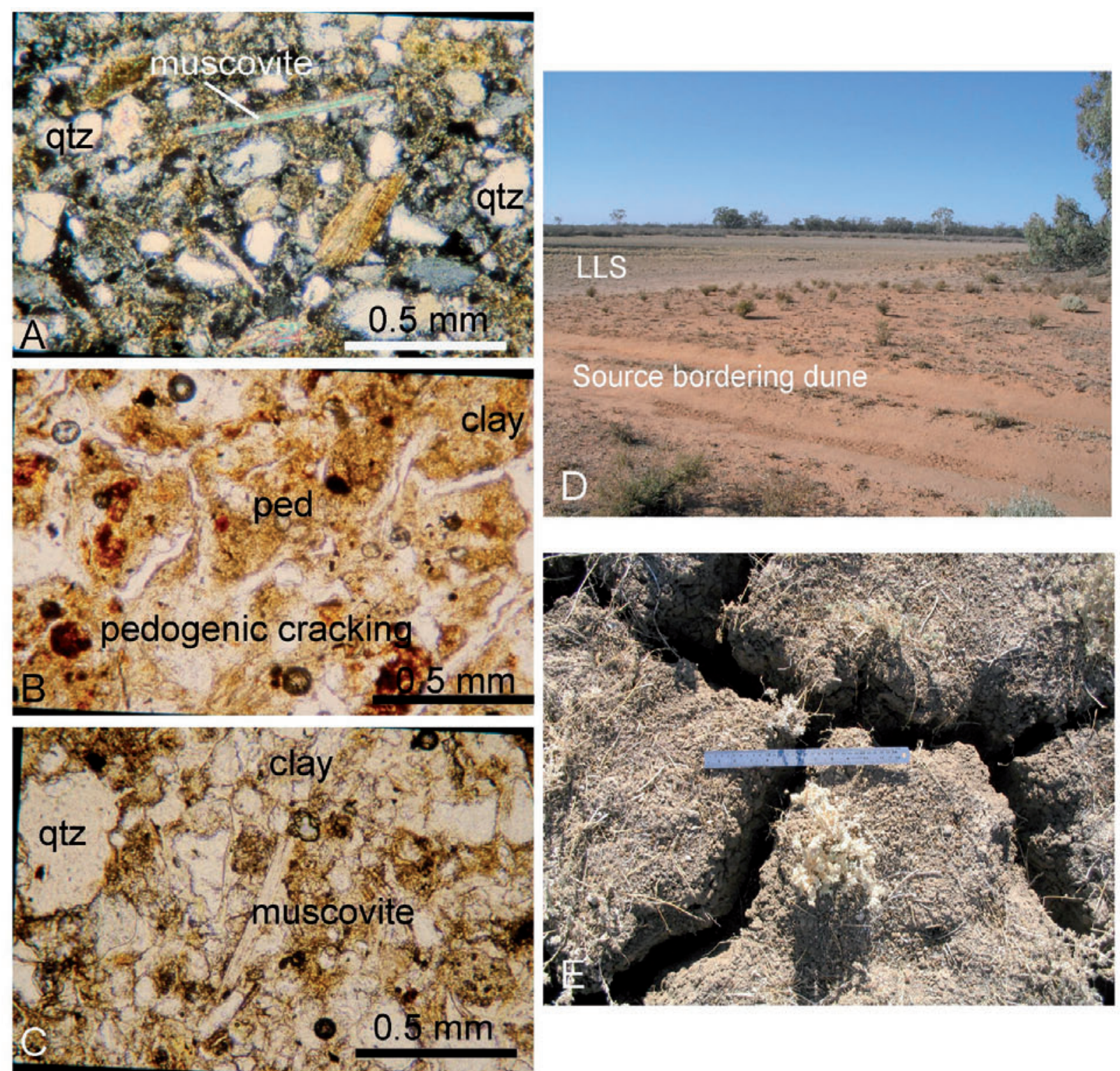

Figure 4. Photomicrographs and field photographs from the lower three land systems.

A: Thin section of typical gilgai floodplain sediments from the Lindsay Land System. Note the abundance of quartz and clay with significant muscovite (crossed polars)

B: A thin section viewed under plain light showing pedal development in the upper clay-rich sediments of the Mulcra Island Land System. The peds are a reflection of cyclic wetting and drying regimes;

C: Plain light thin section of grey clay alluvium from the Murray Land System terrace. Note the dominance of clay over quartz and the occurrence of muscovite which is characteristic of these fluvial sediments;

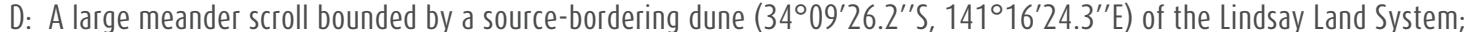

E: Typical gilgai cracking clays from a meander scroll in Lindsay Land System (the ruler is $30 \mathrm{~cm}$ long).

\section{Archaeology and dating}

Climatic conditions influence where humans live by affecting the distribution of water, food, shelter and the availability of raw materials. Geomorphic and stratigraphic evidence sheds light on the environments inhabited by people in the past. Correlating this evidence with analysis of the distribution of cultural material can reveal the human response to changing environments. In the Mallee, this response is reflected in the archaeological record of burials, middens and artefact scatters. 


\section{Archaeological survey}

Archaeological material was recorded at eight locations in the study area. Most of these were on topographic highs such as source bordering dunes and lunettes associated with the Neds Corner and Lindsay Land Systems (Figure 2, Table 3).

\begin{tabular}{lllllll} 
& \multicolumn{4}{c}{ Archaeological material } \\
Site Location & Landform & Freshwater & Freshwater & Stone Hearth Grinding Burials
\end{tabular}

\begin{tabular}{|c|c|c|c|c|c|c|c|c|}
\hline $\begin{array}{l}\text { Homestead } \\
\text { Midden }\end{array}$ & $\begin{array}{l}34^{\circ} 08^{\prime} 08.2^{\prime \prime} \mathrm{S} \\
141^{\circ} 21^{\prime} 40.5^{\prime \prime} \mathrm{E}\end{array}$ & $\begin{array}{l}\text { source- } \\
\text { bordering dune }\end{array}$ & $*$ & * & * & $*$ & & * \\
\hline $\begin{array}{l}\text { Potterwalkagee } \\
\text { Gully }\end{array}$ & $\begin{array}{l}34^{\circ} 09^{\prime} 21.4^{\prime \prime} \mathrm{S} \\
141^{\circ} 20^{\prime} 42.5^{\prime \prime} \mathrm{E}\end{array}$ & $\begin{array}{l}\text { source- } \\
\text { bordering dune }\end{array}$ & $*$ & & & & & \\
\hline Tip Site & $\begin{array}{l}3^{\circ} 09^{\prime} 21.2^{\prime \prime} \mathrm{S} \\
141^{\circ} 20^{\prime} 41.9^{\prime \prime} \mathrm{E}\end{array}$ & $\begin{array}{l}\text { source- } \\
\text { bordering dune }\end{array}$ & $*$ & & * & * & $*$ & * \\
\hline $\begin{array}{l}\text { Lindsay Island } \\
\text { Dune }\end{array}$ & $\begin{array}{l}34^{\circ} 08^{\prime} 32.8^{\prime \prime} \mathrm{S} \\
141^{\circ} 16^{\prime} 51.2^{\prime \prime} \mathrm{E}\end{array}$ & $\begin{array}{l}\text { source- } \\
\text { bordering dune }\end{array}$ & & & & $*$ & $*$ & \\
\hline $\begin{array}{l}\text { Lake } \\
\text { Wallawalla }\end{array}$ & $\begin{array}{l}34^{\circ} 11^{\prime} 51.3^{\prime \prime} \mathrm{S}, \\
141^{\circ} 12018.6^{\prime \prime} \mathrm{E}\end{array}$ & lunette & & & & & & * \\
\hline $\begin{array}{l}\text { Little Lake } \\
\text { Wallawalla }\end{array}$ & $\begin{array}{l}34^{\circ} 12^{\prime} 22.8^{\prime \prime} \mathrm{S}, \\
141^{\circ} 12^{\prime} 17.2^{\prime \prime} \mathrm{E}\end{array}$ & lunette & & & $*$ & $*$ & & * \\
\hline $\begin{array}{l}\text { Subdued } \\
\text { Lunette }\end{array}$ & $\begin{array}{l}34^{\circ} 10^{\prime} 49^{\prime \prime} \mathrm{S}, \\
141^{\circ} 20^{\prime} 32.6^{\prime \prime} \mathrm{E}\end{array}$ & lunette & & & * & * & & \\
\hline Central Rise 1 & $\begin{array}{l}34^{\circ} 12^{\prime} 20.1^{\prime \prime} \mathrm{S} \\
141^{\circ} 12^{\prime} 8.2^{\prime \prime}\end{array}$ & $\begin{array}{l}\text { source- } \\
\text { bordering dune }\end{array}$ & & & $*$ & $*$ & & \\
\hline
\end{tabular}

Table 3. Archaeological material recorded in the study area.

Several different types of archaeological material were found at each location as follows:

- Heat-retainer hearths were recorded at six of the eight locations, all elevated above the level of the plain and always associated with stone artefacts such as flakes and grinding stones. Due to the lack of rock outcrop in the study area, the heat retainers are predominantly baked clay balls (Figure 5a), either in situ or as scattered fragments.

- Burials: three locations containing burials were identified in the study area (Figure 2, Table 3), each including multiple internments. The Potterwalkagee Gully and Homestead Midden locations also contained shell middens and artefact scatters.

- Grinding implements: sandstone grinding implements (mullers and millstones) were found at three sites (Figure 5b, Table 3), all of which had associated hearths. The lack of suitable outcrops of sandstone nearby implies that these implements were imported.

- Stone artefact scatters: predominantly of ferruginised silcrete, were found at four sites in the study area (Figure 2, Table 3), generally associated with hearths. Assemblages comprised worked flakes (average length $5 \mathrm{~cm}$ from 20 measured flakes, Figure $5 \mathrm{c}$ ) and some cores. The most likely source for the stone is the Berribee silcrete quarry to the west of the study area, which is an outcrop of the Karoonda weathering profile above the Parilla Sands (Figure 2b) (Grist 1995).

- Shell middens: three middens were identified in the study area (Figures 2, 5d, Table 3). All were associated with stone artefact scatters and burials. The Homestead Midden (discussed below) was the largest and densest midden recorded. 

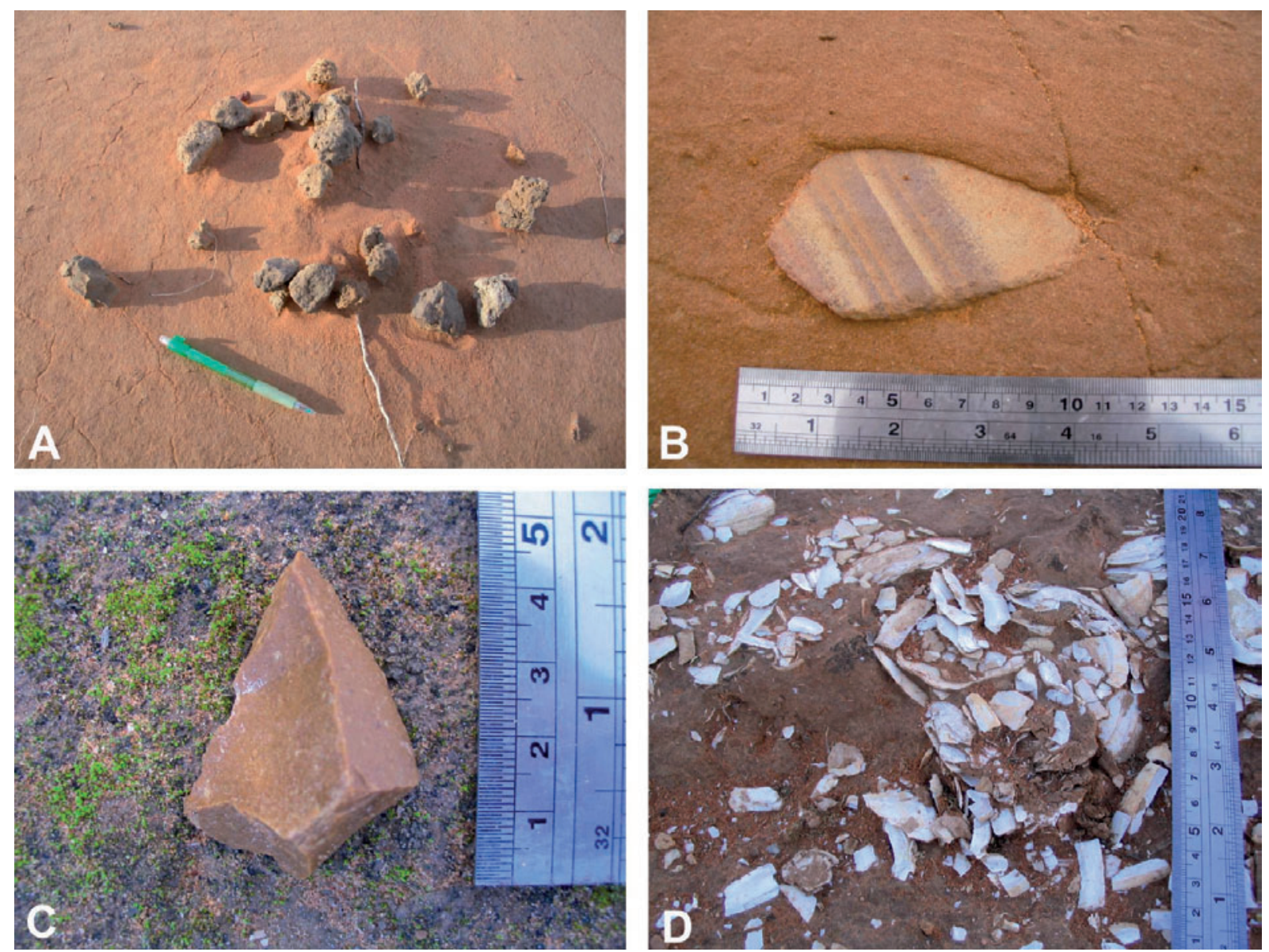

Figure 5. Archaeological deposits found during archaeological survey of the study area.

A: An in situ hearth from the Subdued Lunette site;

B: Sandstone grinding implement (muller) from the Lindsay Island Dune;

C: A silcrete flake from the Homestead Midden;

D: Freshwater mussels (Alathyria jacksoni) from the Tip Site midden. For locations of archaeological sites see Figure 2 and Table 3.

\section{Archaeological excavation}

The Homestead Midden occurs on a source-bordering dune associated with the Lindsay Land System (Figure 2). The dimensions of the midden are approximately $400 \mathrm{~m}$ east-west and $20 \mathrm{~m}$ north-south. Four human burials were observed eroding out of the dune.

Trench 1 was excavated to a depth of $110 \mathrm{~cm}$ (Figure 6). The archaeological deposits ( 70\% Alathyria jacksoni freshwater mussel shells, $10 \%$ Notopala hanlei freshwater snail shells, $20 \%$ sediment, scattered silcrete flakes and clay heat retainers) sit unconformably over a reworked carbonate horizon of the dune surface. This indicates that the cultural material was deposited after stabilisation of the Lindsay Land System, when the Mulcra Island Land System was active (Figure 6). Ferruginised sand stratigraphically overlies the midden, although erosion has exposed some sections at the surface.

Radiometric radiocarbon ages (Table 4) were determined from two excavated Alathyria jacksoni shells. The shells yielded similar ages of 15,000 $\pm 750 \mathrm{cal} \mathrm{BP}$ (Wk-15263) and 15,100 $\pm 750 \mathrm{cal} \mathrm{BP}$ (Wk-15262). 


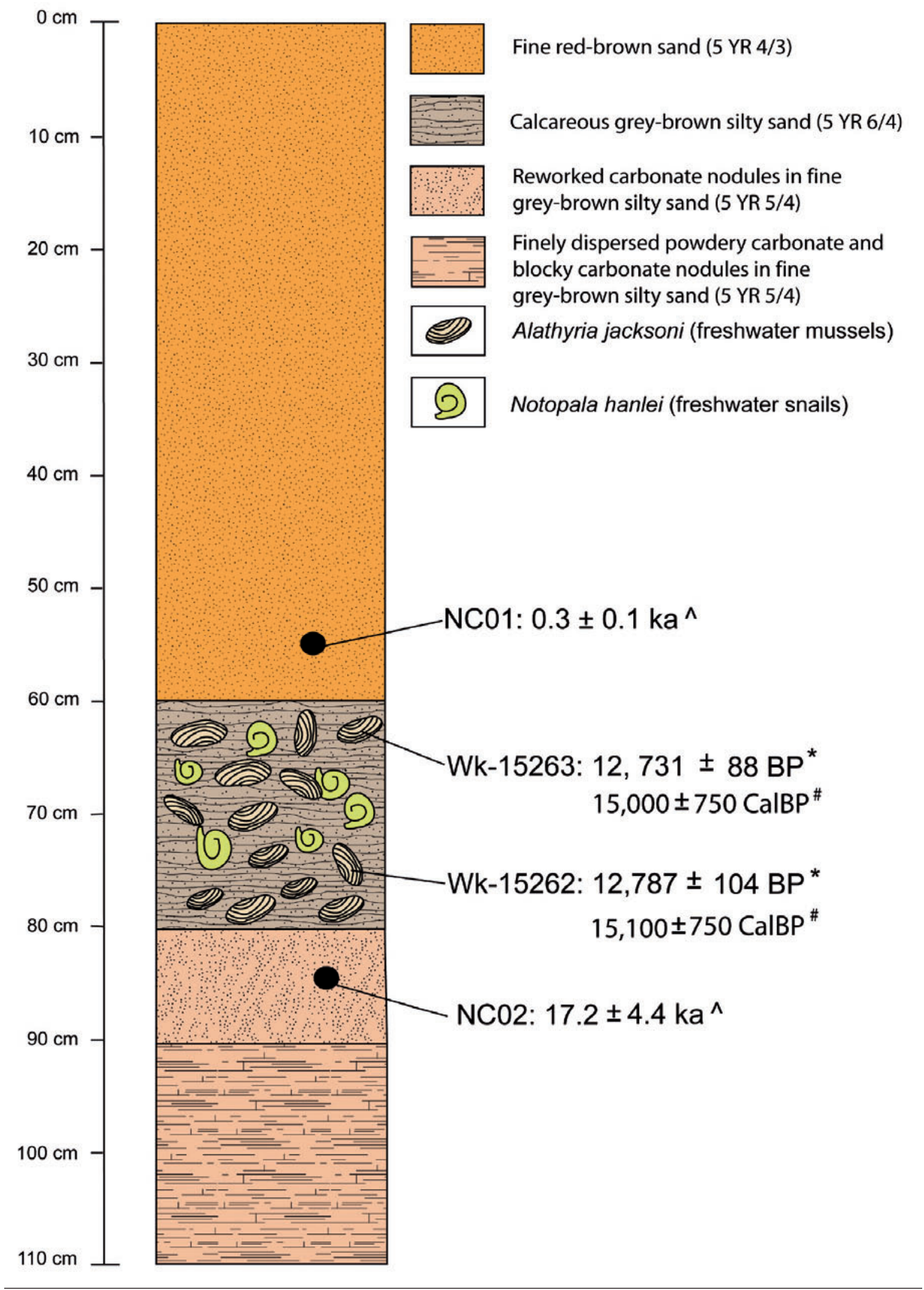

Figure 6. Stratigraphic log of the trench 1 excavation at the Homestead Midden, into source-bordering dune sediments.

$\wedge$ OSL age (Table 6)

* Uncalibrated radiocarbon years before present (Table 5)

\# Calibrated radiocarbon years before present (Table 5). 


\begin{tabular}{|c|c|c|c|c|c|c|c|}
\hline Site & Material & $\begin{array}{l}\text { Lab } \\
\text { Reference } \\
\text { Number }\end{array}$ & $\begin{array}{l}\text { Depth } \\
\text { (cm) }\end{array}$ & $\begin{array}{l}\text { Uncalibrated } \\
\text { Radiocarbon } \\
\text { Age }^{\mathrm{a}}\end{array}$ & $\begin{array}{l}\text { Calibrated } \\
\text { Radiocarbon } \\
\text { Age }^{\mathrm{b}}\end{array}$ & $\begin{array}{l}\text { Geomorphic } \\
\text { Context }\end{array}$ & $\begin{array}{r}\delta^{13} \mathrm{C} \\
(\%)\end{array}$ \\
\hline $\begin{array}{l}\text { Homestead } \\
\text { Midden } \\
\text { trench } 1\end{array}$ & $\begin{array}{l}\text { Alathyria } \\
\text { jacksoni } \\
\text { shell } \\
\text { (aragonite) }\end{array}$ & Wk-15262 & $70 \mathrm{~cm}$ & $\begin{array}{l}12,787 \\
\pm 104 \mathrm{BP}\end{array}$ & $\begin{array}{l}15,100 \\
\pm 750 \text { CalBP }\end{array}$ & $\begin{array}{l}\text { source- } \\
\text { bordering } \\
\text { dune }\end{array}$ & $\begin{array}{l}-9.7 \\
\pm 0.2\end{array}$ \\
\hline $\begin{array}{l}\text { Homestead } \\
\text { Midden } \\
\text { trench } 1\end{array}$ & $\begin{array}{l}\text { Alathyria } \\
\text { jacksoni } \\
\text { shell } \\
\text { (aragonite) }\end{array}$ & Wk-15263 & $60 \mathrm{~cm}$ & $\begin{array}{l}12,731 \\
\pm 88 \mathrm{BP}\end{array}$ & $\begin{array}{l}15,000 \\
\pm 750 \text { CalBP }\end{array}$ & $\begin{array}{l}\text { source- } \\
\text { bordering } \\
\text { dune }\end{array}$ & $\begin{array}{l}-9.1 \\
\pm 0.2\end{array}$ \\
\hline
\end{tabular}

a: mean $\pm 1 \sigma$ uncertainty

b: mean $\pm 2 \sigma$ uncertainty

Table 4. Conventional and calibrated radiocarbon ages from the Homestead Midden, Ned's Corner Station

Two sediment samples overlying archaeological deposits from the Homestead Midden (Figure 6) and nearby Potterwalkagee Gully (Table 3) yielded identical OSL ages of $0.3 \pm 0.1$ ka (Figure 6, Table 5). These young ages may indicate reworking of the dune surface immediately after European contact. The ages from the upper and lower horizons of the Homestead Midden $(0.3 \pm 0.1 \mathrm{ka}$ and $17.2 \pm 4.4 \mathrm{ka}$ respecti vely) are in stratigraphic agreement with the radiocarbon ages $(15,000 \pm 750 \mathrm{cal} \mathrm{BP}$ and 15,100 $\pm 750 \mathrm{cal}$ BP), whilst an age of $11.1 \pm 1.9$ ka from Potterwalkagee Gully midden sediments is slightly younger than the excavated midden deposits.

\section{Discussion: Environmental evolution and archaeology of the central Murray Valley}

The soils, sediments and landforms of the central Murray Valley preserve evidence of environmental evolution throughout the last glacial cycle. Incorporation of archaeological evidence allows an evaluation of the human response to environmental changes as these human populations would have needed to adapt their settlement, hunting and foraging activities to the changing environment as the landscape evolved through successive arid and humid cycles.

\section{The fluvial activation of the Neds Corner Land System: >40 - 24 ka}

The Neds Corner Land System preserves evidence of multiple phases of environmental evolution in its fluvial, aeolian and lacustrine landforms. The oldest units are floodplain and palaeochannel sequences with morphologies markedly different from the modern Murray fluvial system (Table 2). These differences imply a contrasting hydrological regime, likely to reflect divergent climatic conditions (Drury 1967). A change in channel morphology also connotes a change in fluvial load. While the present regime is characterised by suspended-load, low flow rates and sinuous channels, the larger, laterallymigrating channels of the Neds Corner Land System may have resulted from bedload-dominated flow regimes (Page and Nanson 1996). This interpretation is consistent with the coarser sandy channels and source-bordering dunes observed on the Neds Corner land surface (Table 1). In Australia, sourcebordering dunes are associated only with relict channel systems (Bowler and Magee 1978; Mabbutt 1980; Williams et al. 1991; Page et al. 2001). Their formation is a result of reduced vegetation, high bedload and a strong component of seasonal flow (Bowler 1986a; Page et al. 1991; Page and Nanson 1996; Bullard and McTainsh 2003). 


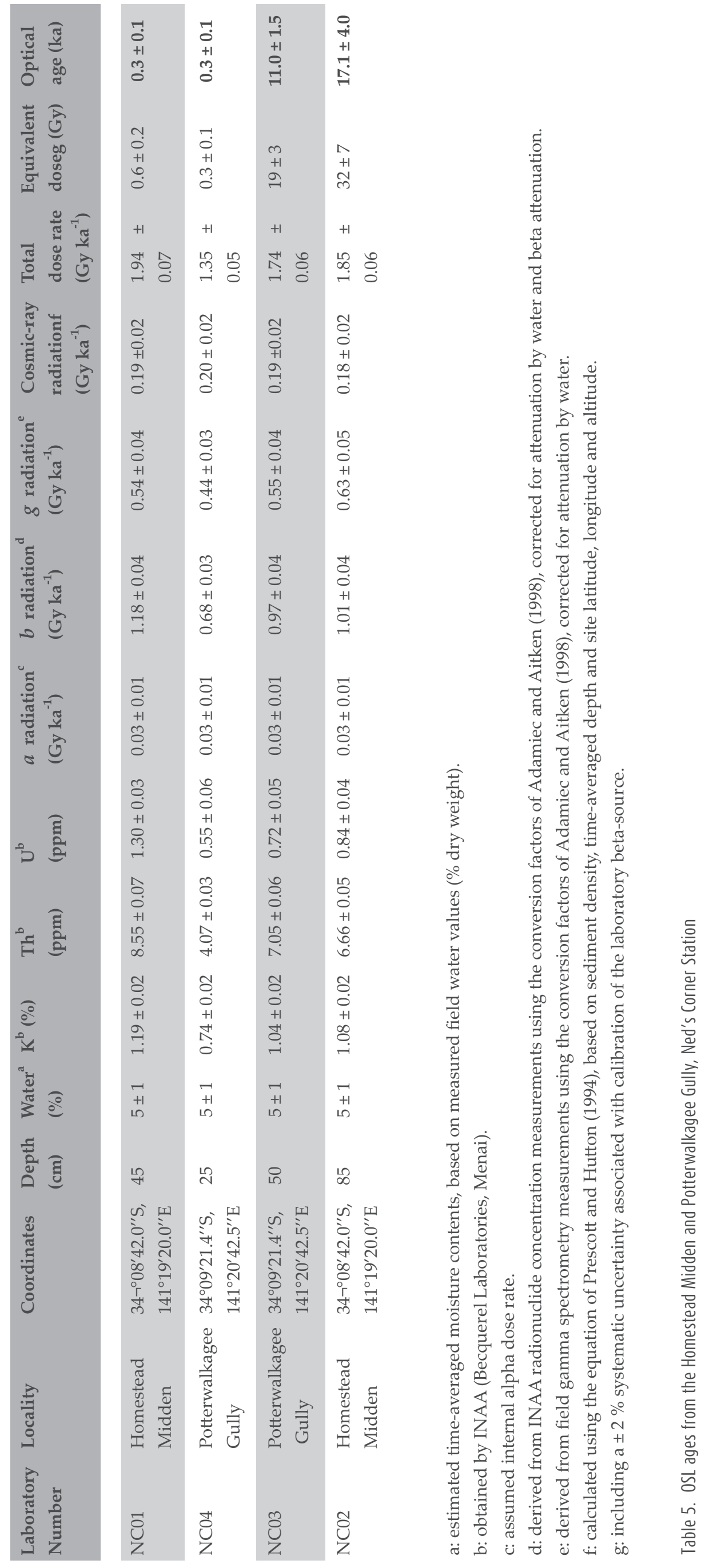


The degree of pedogenesis in the Neds Corner Land System fluvial horizons, together with the accumulation of $\sim 30 \mathrm{~cm}$ of aeolian dust above the floodplain surface, suggest that this fluvial activity is substantially older than the other land systems identified by this study (Figure 3). Although this sequence has not been dated, its relative age can be inferred by comparison with equivalent fluvial sequences in the adjacent Riverine Plain. Channels of the Green-Gully Tallygaroopna system (Bowler 1978), like the Neds Corner channels, are wide, laterally migrating, bedload-dominated and associated with source-bordering dunes. Both sequences are highly pedogenised. Channel widths and meander wavelengths are comparable with those of the Neds Corner fluvial system, suggesting that both channel sequences represent the same regime of greater seasonal discharge. Bowler (1978) estimated the GreenGully Tallygaroopna channels to be at least 40,000 years old. This assumption has been substantiated by recent OSL dating of these sequences (Dr Tim Stone, pers. comm.).

Climatic conditions at this time were more arid than today. The apparent contradiction between drier conditions and increased surface flow is a function of enhanced effective precipitation: as vegetation decreased during arid, glacial periods, infiltration was reduced. Furthermore, periglacial conditions in highland catchments have the effect of increasing runoff. Discharge is increased even though actual precipitation may be reduced (Barrows et al. 2001).

This fluvial regime was probably active as far back as the commencement of Oxygen Isotope Stage 3, when global climates became relatively more arid. The initiation of this fluvial regime may correspond to the Snowy River Glacial Advance in the southeastern highlands at 59.3 \pm 5.4 ka (Barrows et al. 2001, 2002). Further glacial advances in the Late Pleistocene such as the first advance in the Kosciusko glaciation at $32 \pm 2.5$ ka may also have influenced the aggradation of this system with increasing aridity.

\section{Aeolian activity of the Neds Corner Land System and activation of the fluvial Lindsay Land System:} Oxygen Isotope Stage 3 to the last glacial maximum

Significant dust transport, represented by $\sim 30 \mathrm{~cm}$ of parna accumulation on the floodplain surface followed the final phase of channel evolution in the Neds Corner Land System (Figure 3). This implies intensification of the arid conditions, which culminated during the last glacial maximum ( 24-18 ka) (Mix and Schneider 2001). The polycyclic clay cutans and higher degree of carbonate pedogenesis in the lower part of the parna profile indicate successive depositional cycles. The first phase of aeolian mobilization is likely to have occurred late in Oxygen Isotope Stage $3(\sim 64-32 \mathrm{ka})$, coeval with a significant dust flux recorded throughout southeastern Australia (Bowler 1986b; Wasson 1989; Page and Nanson 1996).

The last major phase of parna dispersal is likely to have coincided with the last glacial maximum (Butler 1956; Bowler 1976, 1986a; Bowler et al. 1976; Wasson and Donnelly 1991; Hesse et al. 2003; Hesse and McTainsh 2003). Aluminium- and quartz-rich aeolian detritus within the Vostok ice core are indicative of the greater wind speeds and dust mobilization that occurred during the last glacial maximum (McTainsh 1989; Petit et al. 1990). Cool, arid conditions peaked at $\sim 20 \mathrm{ka}$. Sea level was $\sim 120 \mathrm{~m}$ below present, which increased aridity and landmass area, linking the Australian mainland with New Guinea and Tasmania (Williams et al. 1998). Continental temperatures were 6-10 ${ }^{\circ} \mathrm{C}$ lower than modern temperatures (Harrison and Dodson 1993, Harrison and Prentice 2003). Palynological evidence from Lake Frome, South Australia shows decreased woodland vegetation at this time, enabling strong glacial winds to mobilise sediments for aeolian transport and dune formation (Singh and Luly 1991).

The lunette lakes of the study area incise, and thus postdate, the Neds Corner fluvial channels (Figure 2). Almost all lunettes in Australia are relict, with the exception of some reactivated lunettes at Lakes Tyrrell (Teller et al. 1982) and Eyre (Dulhunty 1983). Thus the lunettes of the Neds Corner Land System provide an insight into previous hydrological conditions (Bowler 1986b). The pelletal clay compositions of the lunettes within the study area indicate that they formed during cool, arid conditions when saline water tables were near the surface (Bowler 1973; Macumber 1980; Dare-Edwards 1984). Lake Wallawalla preserves two lunette phases, which are potentially analogous to the two cycles of parna activity attributed to late Oxygen Isotope Stage 3 and the last glacial maximum. 
The large meander wavelengths, channel widths and associations with source-bordering dunes suggest that, similar to the Neds Corner Land System, the Lindsay Land System consisted of laterallymigrating bedload-dominated fluvial channels with seasonally high discharge to expose point bars and provide a sediment source for source-bordering dune formation (Figure 2, Table 2). Gilgai clays on the floodplain of this land system (Figure 4a) support the notion of increased seasonal flow, with the deep cracks suggesting strong seasonal wetting and drying regimes (Retallack 1997).

Unlike the Neds Corner Land System, the upper surface of the Lindsay Land System does not preserve evidence of parna deposition. This suggests it was fluvially active during or after the last glacial maximum when the last phase of parna deposition occurred. OSL dates of 17.2 $\pm 4.4 \mathrm{ka}$ obtained from Lin dsay Land System source-bordering dunes (Table 5) indicate that activation of the Lindsay palaeochannels was roughly synchronous with lunette dune building and parna accumulation on the Neds Corner land surface. Equivalents of the Lindsay Land System fluvial phase from the Riverine Plain have been identified by Bowler (1978) (Kotupna phase) and Page et al. (1991; Page and Nanson 1996) (Yanco phase), both of which have been dated (by radiocarbon and thermoluminescence) to the last glacial maximum. These systems are characterised by large, laterally migrating meanders, sourcebordering dunes and channel widths wider than the modern River Murray, but smaller than the Neds Corner palaeochannels. These channel forms imply a regime of seasonally high discharge, on a smaller scale than the Neds Corner Land System.

The last advances of the Kosciusko glaciation in the southern highlands occurred at $19 \pm 1.6 \mathrm{ka}$ and $16.8 \pm 1.4 \mathrm{ka}$ (Barrows et al. 2001, 2002). The less extensive advances of these glaciers, compared with the previous glaciations (Barrows et al. 2001), suggest lower precipitation may account for the smaller channel widths and meander wavelengths of the Lindsay Land System compared with the Neds Corner Land System.

The effect of these hyper-arid conditions on human populations is reflected in the lack of archaeological sites in the region dating to the last glacial maximum (Hope 1998; Mulvaney and Kamminga 1999). Glacial conditions would cause a reduction in the availability of food resources, shelter and raw materials. This suggests that as climatic conditions deteriorated, people were forced to retreat towards the coastal margins of Australia. It is only after the last glacial maximum that inland sites were once again colonised (Mulvaney and Kamminga 1999).

\section{Mulcra Island Land System fluvial phase:The transition from glacial conditions}

Channels of the Mulcra Island Land System cut across, and thus must postdate, those of the Lindsay Land System (Figure 2). Several billabongs, characteristic of more sinuous, suspended-load systems (Page and Nanson, 1996), have formed from meander-cutoffs within the Mulcra Island Land System (Figure 2, Table 1). The absence of source-bordering dunes suggests the return of channel-margin vegetation before the conversion to the modern system (Bowler 1978; Page et al. 1991; Page and Nanson 1996; Ogden et al. 2001). The sinuous, mixed- to suspended-load channels of the Mulcra Island Land System (Figure 2, Table 2) imply a change in hydrologic regime at the end of the Lindsay Land System during the last glacial maximum. The relatively larger channels of the Mulcra Island Land System compared with the modern Murray preserve a transitional, deglacial phase of channel evolution, no equivalents of which have been recognised on the Riverine Plain. Between $\sim 17$ and $~ 14.5 \mathrm{ka}$, sufficient rain in the central Murray Valley allowed eucalypt woodland to recolonise and restabilise the landscape (Singh and Luly 1991). This observation is consistent with the higher sinuosity and absence of source-bordering dunes on this system.

From Vostok ice core records, dust flux decreased and temperatures began to increase immediately following the peak of the last glacial maximum, but did not approach modern conditions until the middle Holocene (Barnola et al. 1987; Jouzel et al. 1987; McTainsh 1989). Global sea levels gradually rose following the end of the last glacial maximum, with a rapid increase at $15 \mathrm{ka}$ from the melting of North American ice sheets (Chappell 1993). The final retreat of glaciers from the southeastern highlands at $16.8 \pm 1.4 \mathrm{ka}$ (Barrows et al. 2001, 2002, 2004), may have supplied the climatic impetus for this change in hydrologic regime. By inference, the evolution from bedload to suspended load channels was probably more gradual than has previously been assumed from studies of the Riverine Plain. 
Some studies contend that substantial occupation of the central Murray Valley region did not occur until the Late Holocene, with the most intensive settlement in the last 2000 years (Ross 1981, 1982 1985; Hope 1998). However, radiocarbon ages from the surrounding regions (Edmonds 2004) show a spread of ages over a greater period, with a significant number of dates clustering around the terminal Pleistocene and early Holocene. The 15,000 cal BP dates obtained from this study as well as large shell midden accumulations on source-bordering dunes suggest substantial occupation, at least of the riparian margins, during the Mulcra Island climatic phase. At this time, the river evolved from a high-velocity bedload-dominated regime to a mixed- to suspended-load sinuous channel system. The change in fluvial regime would have increased the resource potential of the riparian margins (Mulvaney and Kaminga 1999). As the channel became narrower and more sinuous, water temperature increased and current velocity decreased, creating conditions more conducive to the support of fish and mollusc populations. Billabongs, characteristic of this land system, provided an additional resource as seasonal wetlands, attracting bird and mammal populations, which could be hunted for their meat, skins, sinew and bone for tools.

\section{Murray Land System fluvial phase: The Holocene}

The higher sinuosity, smaller channel width, and smaller meander wavelengths of the Murray Land System are a function of the current fluvial regime: a suspended-load, low-gradient flow system (Table 2). Change towards modern regimes in both the Mallee and the Riverine Plain is likely to have been gradual, occurring some time in the early Holocene. Bowler (1978) has dated this change to $9 \mathrm{ka} \mathrm{BP}$, which is coeval with an increase in woodland vegetation at Lake Frome (Singh et al. 1981). Decreased runoff due to the presence of woodland vegetation, along with increasing summer insolation throughout the Holocene, caused increased evaporation to deplete water availability, reducing flow peaks and decreasing channel and meander size (Harrison and Dodson 1993).

During natural flow conditions in the Holocene, the Murray River dried to a series of saline water holes, which would have necessitated the exploitation of the surrounding Mallee hinterland (Pardoe 1990; Cupper 2003). Elevated regions (such as lunettes) may have been used as campsites for short term or seasonal hunting and gathering expeditions. The surface artefact deposits on dry lake floors and relict dunes in the study area may reflect such seasonal occupation. These deposits are low density, unstratified and clearly postdate the last glacial maximum active phase of the lacustrine units in the Neds Corner Land System.

A variety of food resources are found in the hinterland, including seeds from saltbush that could have been processed with grinding stones like those found at Little Lake Wallawalla, Tip Site and Lindsay Island Dune (Figure 2, Table 3). The presence of grinding implements suggests that these sites may be Holocene as previous studies have shown grinding implements to be a late Holocene innovation in arid and semi-arid Australia (Ross 1981; Ross et al. 1992).

\section{Conclusions}

This project addresses a previously unstudied area, linking fluviatile, aeolian and lacustrine systems in the central Murray Basin. A multidisciplinary approach to a complex set of environmental parameters inevitably poses more questions than it answers. However, through application of land systems mapping and archaeology, significant conclusions emerge.

Five land systems have been identified in the central Murray Valley, each reflecting different hydrological and climatic regimes. The Neds Corner, Lindsay, Mulcra Island and Murray Land Systems show a progressive evolution from large, laterally-migrating bedload-dominated regimes to the modern Murray River regime of narrow, highly sinuous, suspended-load channels. The progression of fluvio-aeolian-lacustrine environments observed within the study area demonstrates climatic evolution through successive humid-arid cycles. 
Extensive archaeological evidence is preserved in the study area. OSL and radiocarbon dating show that humans were present in the landscape from at least 15,000 years ago. This was a time when the fluvial regime and climate was substantially different from that of today. The climate was shifting from the aridity caused by the last glacial maximum towards the characteristic humid Holocene climates. The recognition of fluvial and aeolian environments presents background for the interpretation of human adaptation to changing environmental regimes in this part of the Murray Basin.

\section{Acknowledgements}

Thank you to Aboriginal Affairs Victoria, particularly Mark Dugay-Grist for supporting the work and securing funding for radiocarbon dating, and to Latje Latje community for allowing this work on their land. Trust for Nature provided logistical support. Gordon Holm assisted with thin section preparation. Chris Rowley and Brian Smith identified the sub-fossil shell species. Tim Stone and Malcolm Wallace provided constructive advice throughout the project. The authors are grateful to Dr Patricia Fanning, Dr Adrian Fisher and one anonymous reviewer for their helpful reviews of an earlier draft of the manuscript. 


\section{References}

Adamiec, G. and M. J. Aitken. 1998. Dose-rate conversion factors: Update. Ancient TL 16, 37-50.

Barnola, J. M., D. Raynaud, Y. S. Korotkevich and C. Lorius. 1987. Vostok ice core provides 160,000-year record of atmospheric CO2. Nature 329:408-414.

Barrows, T. T., J. O. Stone, L. K. Fifield and R. G. Cresswell. 2001. Late Pleistocene glaciation of the Kosciusko massif, Snowy Mountains, Australia. Quaternary Research 55(2):179-189.

Barrows, T. T., J. O. Stone, L. K. Fifield and R. G. Cresswell. 2002. The timing of the last glacial maximum in Australia. Quaternary Science Reviews 21(1-3):159-173.

Barrows, T. T., J. O. Stone and L. K. Fifield. 2004. Exposure ages for Pleistocene periglacial deposits in Australia. Quaternary Science Reviews 23:697-708.

Bullard, J. E. and G. H. McTainsh. 2003. Aeolian-fluvial interpretations in dry land environments: Examples, concepts and Australia case study. Progress in Physical Geography 27(4):471-501.

Butler, B. E. 1956. Parna, an aeolian clay. Australian Journal of Science 18(5):145-151.

Chappell, J. 1993. Late Pleistocene coasts and human migrations in the Austral region. In M Spriggs, D.

E.Yen, W. Ambrose, R. Jones, A. Thorne and A. Andrews (eds), pp 13-17. A Community of Culture. Canberra: Australian National University Press.

Christian, C. S. and G. A. Stewart. 1952. Summary of general report of survey of Katherine-Darwin region.

Churchward, H. M. 1961. Soil studies at Swan Hill, Victoria, Australia. Journal of Soil Science 12:73-86.

Cupper, M. L. 2003. Late Quaternary environments of playas in southwestern New South Wales. Unpublished PhD, Melbourne: University of Melbourne.

Dare-Edwards, A. J. 1984. Aeolian clay deposits of southeastern Australia - parna or loessic clay. Transactions of the Institute of British Geographers 9(3):337-344.

Dulhunty, J. 1983. Lunettes of Lake Eyre North, South Australia. Transactions of the Royal Society of South Australia 107:219-22.

Dury, G. H. 1967. Climatic change as a geographical backdrop. Australian Geographer 10:231-242.

Edmonds, V. 2004. Indigenous Cultural Heritage assessment. Proposed culvert replacement, Lake Wallawalla, northwest Victoria. Buronga NSW: Archaeological Consulting Service for Sinclair Knight Merz, Melbourne.

Galbraith, R. F., R. G. Roberts, G. M. Laslett, H. Yoshida and J. M. Olley. 1999. Optical dating of single and multiple grains from Jimnium rock shelter, part 1: Experimental design and statistical methods. Archaeometry 41:339-364.

Gerard, A. J. 1981. Soils and landforms: An integration of geomorphology and pedology. London: Allen and Unwin.

Grist, M. J. 1995. An archaeological investigation into the 'No Stone Saga' of far Northwest Victoria: A study of the Berribee quarries in the landscape. Unpublished Honours Thesis. Canberra: Australian National University.

Harrison, S. P. and J. R. Dodson. 1993. Climates of Australia and New Guinea since 18,000 yr BP. In H. E. Wright, J. E. Kutzbach, T. Webb and W. F. Ruddiman (eds), pp 265-294. Global climates since the last glacial maximum. Minneapolis: University of Minnesota Press.

Harrison, S. P. and A. I. Prentice. 2003. Climate and CO2 controls on global vegetation distribution at the last glacial maximum: Analysis based on palaeovegetation data, biome modelling and palaeoclimate simulations. Global Change Biology 9(7):983-1004.

Hesse, P. P. and G. H. McTainsh. 2003. Australian dust deposits: Modern processes and the Quaternary record. Quaternary Science Reviews 22(18-19):2007-2035.

Hesse, P. P., G. S. Humphreys, B. L. Smith, J. Campbell and E. K. Peterson. 2003. Age of loess deposits in the Central Tablelands of New South Wales. Australian Journal of Soil Research 41(6):1115-1131.

Hope, J. 1998. Lake Victoria: Finding the balance. Canberra: Murray-Darling Basin Commission. 
Jouzel, J., C. Lorius, J. R. Petit, C. Genthon, N. I. Barkov, V. M. Kotlyakov and V. M. Petrov. 1987. Vostok ice core: A continuous isotope temperature record over the last climatic cycle (160,000 years). Nature 329:403-408.

Mabbut, J. A. 1980. Some general characteristics of the aeolian landscapes. In R. R. Storrier and M. E. Stannard (eds), Aeolian landscapes in the semi-arid zone of south-eastern Australia, pp 1-15. Wagga Wagga: Australian Society for Soil Science, Riverina Branch.

Macumber, P. G. 1980. The influence of groundwater discharge on the Mallee landscape. In R. R. Storrier and M. E. Stannard (eds), Aeolian landscapes in the semi-arid zone of south-eastern Australia, pp 67-84. Wagga Wagga: Australian Society for Soil Science, Riverina Branch.

McTainsh, G. H. 1989. Quaternary aeolian dust processes and sediments in the Australian region. Quaternary Science Reviews 8:235-253.

Mix, A. C. and Schneider, R. 2001. Environmental processes of the ice age: Land, oceans, glaciers. Quaternary Science Reviews 20:627-657.

Mulvaney, D. J. and J. Kamminga. 1999. Prehistory of Australia. Sydney: Allen and Unwin.

Murray-Darling Basin Commission. 1996. River Murray mapping: Colour infrared orthophotography and natural resource data. Canberra: Murray-Darling Basin Commission.

O'Connell, J. F. and J. Allen. 2004. Dating the colonization of Sahul (Pleistocene Australia-New Guinea): A review of recent research. Journal of Archaeological Science 31:835-853.

Ogden, R., N. Spooner, M. Reid and J. Head. 2001. Sediment dates with implications for the age of the conversion from palaeochannel to modern fluvial activity on the Murray River and tributaries. Quaternary International 83-5:195-209.

Page, K. J., A. J. Dare-Edwards, J. W. Owens, P. S. Frazier, J. Kellett and D. M. Price. 2001. TL chronology and stratigraphy of riverine source bordering sand dunes near Wagga Wagga, New South Wales, Australia. Quaternary International 83:187-193.

Page, K. J., and G. C. Nanson. 1996. Stratigraphic architecture resulting from Late Quaternary evolution of the Riverine Plain, south-eastern Australia. Sedimentology 43(6):927-945.

Page, K. J., G. C. Nanson and D. M. Price. 1991. Thermoluminescence chronology of Late Quaternary deposition on the riverine plain of south-eastern Australia. Australian Geographer 22(1):14-23.

Pardoe, C. 1990. The demographic basis of human evolution in southeastern Australia. In B. Meehan (ed.), Hunter-gatherer demography: Past and present, pp 59-70. Sydney: University of Sydney.

Petit, J. R., L. Mournier, J. Jouzel, Y. S. Korotkevich, V. M. Kotyakov and C. Lorius. 1990. Palaeoclimatological and chronological implications of the Vostok core dust record. Nature 343:56-58.

Prescott, J. R. and J. T. Hutton. 1994. Cosmic ray contributions to dose rates for luminescence and ESR dating: Large depths and long-term time variations. Radiation Measurements 23:497-500.

Readhead, M. 1990. TL dating of sediments from Lake Mungo and Nyah West. In R. Gillespie (ed.), Papers Presented at the Quaternary Dating Workshop, pp 35-37. Canberra: Department of Biogeography and Geomorphology, Research School of Pacific Studies, Australian National University.

Retallack, G. J. 1997. A colour guide to paleosols. New York: John Wiley and Sons.

Ross, A. C. 1981. Holocene environments and prehistoric site patterning in the Victorian Mallee. Archaeology in Oceania 16:145-154.

Ross, A. C. 1982. Problems of disentangling human and climatic influences upon the Australian landscape. In B. G. Thom and R. J. Wasson (eds), Holocene research in Australia, pp 29-35. Duntroon: Royal Military College.

Ross, A. C. 1985. Archaeological evidence for population change in the middle to late Holocene in southeastern Australia. Archaeology in Oceania 20:81-89.

Ross, A. C., T. H. Donnelly and R. J. Wasson. 1992. The peopling of the arid zone: Human-environment interactions. In J. R. Dodson (ed.), The naive lands, pp 76-114. Melbourne: Longman Cheshire. 
Rowan, J. N. and R. G. Downes. 1963. A study of the land in north-western Victoria. Victoria: Soil Conservation Authority.

Singh, G., N. D. Opdyke and J. M. Bowler. 1981. Late Cainozoic stratigraphy, paleomagnetic chronology and vegetational history from Lake George, NSW. Journal of the Geological Society of Australia 28(3-4):435-454.

Singh, G. and J. G. Luly. 1991. Changes in vegetational and seasonal climate since the last full glacial at Lake Frome, South Australia. Palaeogeography, Palaeoclimatology, Palaeoecology 84:75-86.

Stone, T., and M. L. Cupper. 2003. Last glacial maximum ages for robust humans at Kow Swamp, southern Australia. Journal of Human Evolution 45(2):99-111.

Teller, J. T., J. M. Bowler and P. G. Macumber. 1982. Modern sedimentation and hydrology in Lake Tyrrell, Victoria. Journal of the Geological Society of Australia 29:159-175.

Wasson, R. J. 1989. Landforms. In J. C. Noble and R. A. Bradstock (eds), Mediterranean landscapes in Australia, pp 13-34. Canberra: CSIRO.

Wasson, R. J. and T. H. Donnelly. 1991. Palaeoclimatic reconstructions for the last 30,000 years in Australia a contribution to prediction of future climate. Canberra: CSIRO Division of Water Resources.

Williams, M. A. J., P. De Deckker, D. A. Adamson and M. R. Talbot. 1991. Episodic fluviatile, lacustrine and aeolian sedimentation in a Late Quaternary desert margin system, central western New South Wales. In D. F. Williams, P. De Deckker and A. P. Kershaw (eds), The Cainozoic in Australia: A reappraisal of the evidence, pp 258-287. Sydney: Geological Society of Australia Inc.

Williams, M. A. J., D. L. Dunkerley, P. De Deckker, A. P. Kershaw and J. M. A. Chappell. 1998. Quaternary environments. London: Arnold. 